\title{
THE POTENTIAL OF MATURE PANDAN LEAVES AS A SOURCE OF CHLOROPHYLL FOR NATURAL FOOD COLORANTS
}

\author{
[Potensi Daun Pandan Tua sebagai Sumber Klorofil untuk Pewarna Makanan Alami]
}

\author{
Chatarina Lilis Suryani ${ }^{1,2)}$, Tutik Dwi Wahyuningsih ${ }^{3)}$, Supriyadi ${ }^{1)}$, and Umar Santoso ${ }^{1 \text { * }}$ \\ 1) Department of Food Technology and Agricultural Products, Faculty of Agricultural Technology, Gadjah Mada University, Yogyakarta \\ ${ }^{2)}$ Department of Food and Agricultural Products Technology, Faculty of Agroindustry, Mercu Buana University, Yogyakarta \\ ${ }^{3)}$ Department of Chemistry, Faculty of Mathematics and Natural Sciences, Gadjah Mada University, Yogyakarta
}

Received May $7^{\text {th }} 2020 /$ Accepted November $2^{\text {nd }} 2020$

\begin{abstract}
Plant leaves are the primary source of natural colorants for food, mainly due to their chlorophyll content. However, the plant types and the degree of leaf maturity determine the quality and quantity of the chlorophyll. This study aimed to determine the best maturity level of pandan (Pandanus amaryllifolius Roxb.) leaves that serves as potential source of chlorophyll for natural food colorants. Eighty three pandan plants obtained from six different farming locations in Bantul Regency, Yogyakarta, Indonesia were used as samples. The leaves were grouped into four levels of maturity using descriptive statistics based on their morphology, anatomy, color, and chlorophyll contents. The results showed that the average number of leaves ranged from 20-24 leaves per plant (at 95\% confidence interval), and $96.4 \%$ of the plant had a maximum of 24 leaves. The leaf maturity was grouped into (1) young, (2) medium, (3) mature, and (4) over mature, corresponding to leaf number 1-6, 7-12, 13-18, and 19-24, respectively. The higher the leaf maturity, the higher the chlorophyll content. However, the over mature leaves were only slightly different from the mature ones. In addition, pandan leaves have specific flavor and contain carotenoid, phenolic, and flavonoid substances. Anatomically, the mesophyll's size was greatest in the mature leaves, while the size of chloroplast was not significantly different from medium to over mature leaves. Based on the chlorophyll content and mesophyll size, it was concluded that mature pandan leaves were the best source of chlorophyll, containing chlorophyll of $623.08 \mathrm{mg} / 100 \mathrm{~g}$ dry weight (DW).
\end{abstract}

Keywords: chlorophyll, food colorants, leaf maturity, Pandanus amaryllifolius Roxb., photomicrography

\section{ABSTRAK}

Daun merupakan sumber utama pewarna alami untuk makanan terutama karena kandungan klorofilnya. Namun, jenis tanaman dan tingkat ketuaan daun menentukan kualitas dan kadar klorofil. Penelitian ini bertujuan untuk mengetahui tingkat ketuaan terbaik daun pandan (Pandanus amaryllifolius Roxb.) sebagai sumber klorofil potensial untuk pewarna alami pangan. Sebanyak 83 tanaman pandan digunakan sebagai sampel, yang diperoleh dari enam lokasi pertanian berbeda di Kabupaten Bantul, Yogyakarta, Indonesia. Daun dikelompokkan dalam empat kelompok berdasarkan tingkat ketuaan daun menggunakan statistik deskriptif dan dianalisis morfologi, anatomi, warna, dan kadar klorofilnya. Hasil penelitian menunjukkan bahwa rata-rata jumlah daun antara 20-24 ruas (pada tingkat kepercayaan 95\%) dan 96,4\% mempunyai jumlah daun maksimal 24 ruas. Tingkat ketuaan daun dikelompokkan menjadi (1) daun muda, (2) medium, (3) tua, dan (4) sangat tua sesuai dengan ruas daun ke 1-6, 7-12, 13-18, dan 1924 setelah tunas, secara berurutan. Semakin tinggi kematangan daun maka semakin tinggi pula kandungan klorofilnya. Namun demikian, pada daun sangat tua hanya berbeda sedikit dengan daun tua. Selain itu, daun pandan memiliki aroma yang khas dan mengandung zat karotenoid, fenolik, dan flavonoid. Secara anatomis, ukuran mesofil paling besar ada pada daun tua, sedangkan ukuran kloroplas tidak berbeda nyata antara daun medium hingga daun tua. Berdasarkan kadar klorofil dan ukuran mesofil dapat disimpulkan bahwa daun pandan yang paling baik sebagai sumber klorofil adalah daun tua dengan kadar klorofil 623,08 mg/100 g berat kering (bk).

Kata kunci: klorofil, Pandanus amaryllifolius Roxb., pewarna makanan, photomicrography, tingkat ketuaan

\footnotetext{
The manuscript has been presented in The $16^{\text {th }}$ Asean Food Conference 2019, October $15^{\text {th }}-18^{\text {th }} 2019$, Bali-Indonesia
} *Corresponding Author: E-mail: umar_s@ugm.ac.id 


\section{INTRODUCTION}

Consumers consider food color as the primary attribute of food before purchasing because it represents the quality and authenticity of the food and indicates successful food processing (Simon et al., 2017; Schifferstein et al., 2019). Recently, food colorants have played a significant role in the food industry with an upward trend in the market and are expected to grow steadily from 10 to $15 \%$ per year (Institute of Food Technology, 2016).

The primary type of colorants that is widely used is synthetic colorants. Synthetic colorants have many advantages over natural colorants, but several studies have shown their adverse effects on human health. Many studies suggested that artificial colorants might cause hyperactivity and learning problems in children (Arnold et al., 2012) and could induce DNA damages in rat colon (Shimada et al., 2010). Therefore, many consumers prefer to choose food with natural colorants as it is considered safe. There are Indonesian indigenous plants that are usually used as a food coloring agent, namely pandan (Pandanus amaryllifolius Roxb.) (Wakte et al., 2012) and suji (Dracaena angustifolia) (Indrasti et al., 2019). Pandan and suji leaves are used as a source of green colorants.

The major substance in pandan leaves that is used as the green coloring agent is chlorophyll. Traditionally, the use of pandan leaves, as natural colorants, is done by mixing pandan leaf extract with food materials during food preparation and processing. However, the color intensity usually decreases during processing. Therefore, the optimization of processing methods to stabilize the color intensity is needed, for example, by the encapsulation process (Porrarud and Pranee, 2010). In the commercial processing of chlorophyll, the feasibility of production must be considered, and the main factor of this feasibility is the chlorophyll content in leaves (Miazek and Ledakowicz, 2013).

The chlorophyll content in leaves is mainly influenced by the type of plants and leaf maturity. Plants as the primary source of commercial chlorophyll production are alfalfa, nettle, spinach, and other types of grasses (Viera et al., 2019). Deveci and Uzun (2011) observed the chlorophyll content in spinach from the initial stage (cotyledon) to the mature stage of plant growth. The results showed that the longer the spinach grew, the higher the chlorophyll content. Kamble et al. (2015) stated that the chlorophyll content of old leaves was higher than that of young leaves in several plants. Besides, Prawira-Atmaja et al. (2018) found that the chlorophyll content in Camellia sinensis var. sinensis leaves was positively correlated with the degree of leaf maturity. However, other researchers argued that during plant growth there is a degradation process of chlorophyll (Hörtensteiner and Kräutler, 2011), which occurs enzymatically by peroxidase, $\mathrm{Mg}$-dechelatase, pheophorbide a oxygenase $(\mathrm{PaO})$, red-chlorophyll catabolite reductase, and chlorophyllase enzymes (Indrasti et al., 2018) resulting in decreased chlorophyll levels. Hu et al. (2013) found that the degree of leaf maturity of Arabidopsis thaliana affected its chlorophyll content. The fourmonth aged leaves contained higher chlorophyll than the eight-month aged leaves because chlorophyll might degrade during the over mature period. In addition to chlorophyll degradation, the older the pandan leaves, the higher the fiber content, thus complicating the extraction process leading to low extracted chlorophyll. Interestingly, Limantara et al. (2015) explained that some factors affect the chlorophyll content in commercial green vegetables, namely leaf size, thickness, and variation in chloroplast distribution. Pandan leaf extract had a total chlorophyll content of $17.82 \mathrm{mg} / \mathrm{g}$ fresh weight (FW) (Senklang and Anprung, 2010), while the chlorophyll content in different degrees of leaf maturity has not been studied yet. This study aimed to evaluate the effects of leaf maturity on the chlorophyll content, color, and chemical characteristics of pandan leaves and to determine the best section of pandan leaves as the most potential source of chlorophyll for natural food colorants.

\section{MATERIALS AND METHODS}

\section{Materials}

Pandan leaves were collected from Bantul Regency, Yogyakarta, Indonesia. Sampling was done in September and October 2018 from six different farming locations ( $A, B, C, D, E$, and F) covering 100 plants. However, only 83 plant samples were used for further studies after field selection. The field selection was conducted to gather complete pandan plants whose leaves have not been harvested. Plant samples were wrapped with black polyethylene (PE) plastics and stored in a cooling box while being transported and analyzed.

\section{Leaf maturity classifications}

The morphology of the plant samples was visually observed, and the number of leaves was counted. After that, the leaves were classified into four groups based on the degree of leaf maturity, namely (1) young, (2) medium, (3) mature, and (4) over mature by descriptive statistics as computed using SPSS (IBM, 2011). The number of leaves was determined based on mean estimation by $Z$ distribution at a 95\%-significance level (Mendenhall and Sincich, 2016).

After grouping, the most potential farming location was selected from the six areas. A total of 
12 plants from each garden were analyzed in three replications for their color and chlorophyll content. The data were then analyzed statistically using the one-way analysis of variance (ANOVA) (IBM, 2011). The selected garden was used as the primary source of raw materials for further studies.

Lastly, to determine which group is the best chlorophyll source, each leaf of different maturity levels was taken from two pandan plants obtained from the selected garden location. All the leaf samples were analyzed in three replications for their color and morphology and their proximate, carotenoid, phenolic, flavonoid, and chlorophyll contents. The data were analyzed statistically using ANOVA (IBM, 2011).

\section{Determination of chlorophyll contents (Nikolaeva et al., 2010)}

Briefly, fresh pandan leaves were cut crosswise at a size of $1-2 \mathrm{~cm}$, dry-milled for three min, weighed accurately $(5.0 \mathrm{~g})$, extracted with $20 \mathrm{~mL}$ of acetone (Merck, Germany), mixed, and centrifuged at 8,000 rpm for $15 \mathrm{~min}$. The supernatant was then filtered with the Whatman filter paper grade 1 and 42 with pore sizes of 11 and $2.5 \mu \mathrm{m}$, respectively, and adjusted to $25 \mathrm{~mL}$ in a volumetric flask. The absorbance value of the extract was measured by a UVVis spectrophotometer (Shimadzu, Japan) at 663 and $645 \mathrm{~nm}$. Total chlorophyll, chlorophyll a, and chlorophyll $b$ contents were calculated by the equation (1), (2), and (3), in which $\mathrm{fw}=$ fresh weight, $D F=$ dilution factor, and $\mathrm{W}=$ sample weight.

Total Chlorophyll $(\mathrm{mg} / \mathrm{g} \mathrm{fw})=$

$\left(20.24 A_{645}+8.02 A_{663}\right) \times \frac{D F}{(W \times 1000)}$

Chlorophyll a $(\mathrm{mg} / \mathrm{g} \mathrm{fw})=$

$\left(12.70 A_{663}-2.69 A_{645}\right) \times \frac{D F}{(W \times 1000)}$

Chlorophyll b $(\mathrm{mg} / \mathrm{g} \mathrm{fw})=$

$\left(22.90 \mathrm{~A}_{645}-4.69 \mathrm{~A}_{663}\right) \times \frac{\mathrm{DF}}{(\mathrm{W} \times 1000)}$

\section{Determination of color values (Pathare et al., 2013)}

The color values of pandan leaves were determined using Chromameter (CR-400, Konica Minolta Optic Inc., Japan) with $L$, $a$, and b color system in which $L$ is for lightness, $+a=$ redness and $-a=$ greenness $(-)$, and $+b=$ yellowness, and $-b=$ blueness. Chroma (C) and hue $\left(h^{\circ}\right)$ were computed using equation (4) and (5).
$C=\sqrt{\left(a^{2}+b^{2}\right)}$

hue $\left(h^{\circ}\right)=\arctan \frac{b}{a}$

\section{Determination of total carotenoid content (Khandaker et al., 2012)}

Total carotenoid was determined by the spectrophotometric method. Briefly, fresh pandan leaves were cut crosswise at a size of 1-2 cm, dry-milled for three min, and weighed accurately $(1.0 \mathrm{~g})$. The slurry sample was extracted with $100 \mathrm{~mL}$ of acetone, stirring until the carotenoids dissolved. The extract was filtered with the Whatman filter paper grade 42 (pore size $=2.5 \mu \mathrm{m}$ ). The absorbance value of the supernatant was measured by a UV-Vis spectrophotometer at wavelengths of 480,646 and $663 \mathrm{~nm}$. The carotenoid content was calculated based on equation (6), in which $\mathrm{V}=$ sample volume $(\mathrm{mL})$ and $\mathrm{W}=$ sample weight $(\mathrm{g})$. Conversion into $\mathrm{mg} / \mathrm{g}$ units was carried out with an average molecular weight of $545 \mathrm{~g} / \mathrm{mol}$ carotenoids.

Total Caratenoid $(\mu \mathrm{mol} / \mathrm{g})=$

$\frac{\left(\left(\mathrm{A}_{480}+\left(0.114 \times \mathrm{A}_{663}\right)-\left(0.638 \times \mathrm{A}_{645}\right)\right) \times\left(\mathrm{V} \times 10^{3}\right)\right.}{112.5 \times \mathrm{W}}$

\section{Determination of total phenolic and flavonoid contents (Pujimulyani et al., 2010)}

Total phenolics were determined by the FolinCiolcalteu method. Briefly, $50 \mu \mathrm{L}$ of extract solution was mixed with $250 \mu \mathrm{L}$ of the Folin-Ciocalteu solution (Sigma Chemical Co., St. Louis) and allowed to stand for one min. Then, $750 \mu \mathrm{L}$ of $20 \% \mathrm{Na}_{2} \mathrm{CO}_{3}$ (Merck, Germany) was added and swirled until homogeneous. The solution was then added with distilled water until $5 \mathrm{~mL}$. After incubation for 2 hours at room temperature, the absorbance was measured with a UV-Vis spectrophotometer at $760 \mathrm{~nm}$. Total phenolics were calculated using a gallic acid standard (Sigma Chemical Co., St. Louis) and expressed as milligram equivalent gallic acid per gram dry weight (mg EAG/g DW).

Total flavonoids were determined by a colorimetric method. Briefly, $50 \mu \mathrm{L}$ of extract, $4 \mathrm{~mL}$ of distilled water, and $0.3 \mathrm{~mL}$ of $10 \% \mathrm{NaNO}_{2}$ solution were mixed in a test tube. After six min, $0.3 \mathrm{~mL}$ of $10 \% \mathrm{AlCl}_{3} \cdot 6 \mathrm{H}_{2} \mathrm{O}$ (Merck, Germany) solution was added and allowed to stand for another five min. After that, $4 \mathrm{~mL}$ of $10 \% \mathrm{NaOH}$ solution was added, and the volume was adjusted to $10 \mathrm{~mL}$ with distilled water and swirled. After incubation for $15 \mathrm{~min}$ at room temperature, the absorbance was measured by a UV-Vis spectrophotometer at $510 \mathrm{~nm}$. The extract was replaced with distilled water as blank. Total flavonoids were calculated using a quercetin stan- 
dard (Sigma Chemical Co., St. Louis) and expressed as milligram equivalent quercetin per gram dry weight (mg EQ/g DW).

\section{Proximate analysis (AOAC, 1990)}

The proximate analysis of pandan leaves was also carried out. The proximate composition includes the moisture, ash, lipid, protein, and carbohydrate contents (by difference) of pandan leaves.

\section{Leaf anatomy measurements (Rahayu et al., 2011)}

The leaf anatomy was observed based on photomicrography of the transverse section of the pandan leaves. Mesophyll width, parenchyma length, and chloroplast size were measured using a binocular microscope (BOECO BM 180-SP, Germany) and a digital microscope camera (Optilab, Upgrade Edition).

\section{Statistical analysis}

IBM SPSS version 20 software (2011) was used to statistically analyze the data with the interpretation based on the One-way Analysis of Variance (ANOVA) and Duncan's Multiple Range Test (DMRT) with a 95\% confidence interval $(P<0.05)$.

\section{RESULTS AND DISCUSSION}

\section{Plant morphology}

Cultivated pandan plants in Bantul Regency grew in clumps (5-15 stems in each clump), creeping on land until a height of 0.5-1.2 m (Figure 1). However, Wakte et al. (2009) mentioned that pandan plants could grow as high as $4.5 \mathrm{~m}$. The stem was cylindrical, $0.5-1.5 \mathrm{~cm}$ in diameter, with a small taproot.

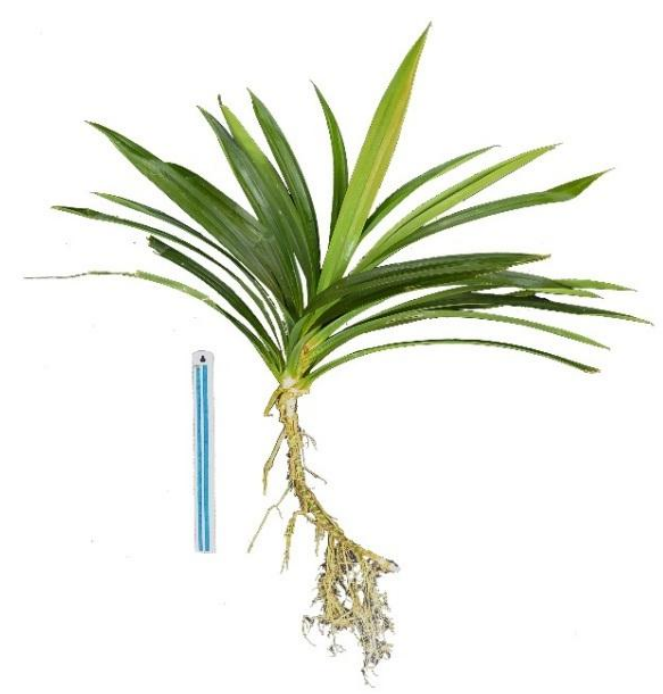

Figure 1. Pandanus amaryllifolius Roxb. plant
The leaves formed a sword-like shape with 19$55 \mathrm{~cm}$ in length and $1.5-3.2 \mathrm{~cm}$ in width (Figure 1). The upper surface of the leaves was bright with prickly tips. In Bantul Regency, pandan plants were cultivated in paddy fields as well as in some private gardens. Two out of the six studied locations were in paddy fields located in Kalipakis, Tirtonirmolo, Kasihan (A) and in Nulis, Argomulyo, Sedayu (F), and the rest were in private gardens (Siyangan, Triharjo, Pandak (B); Gedongsari, Wijirejo, Pandak (C); Dagen, Pendowoharjo, Sewon (D); and Panggang, Argomulyo, Sedayu (E)). Naturally, pandan plants grow in clumps and can consist of many plants per clump without a pre-cutting treatment. Wakte et al. (2009) classified the plant density as (1) low $(<5$ plants per $50 \mathrm{~m}^{2}$ ), (2) medium (5-50 plants per 50 $\left.\mathrm{m}^{2}\right)$, and (3) high (>50 plants per $\left.50 \mathrm{~m}^{2}\right)$. Our survey showed no location with a plant density of fewer than five plants per $50 \mathrm{~m}^{2}$. The plant density in all paddy fields was high or exceeded 50 plants per 50 $\mathrm{m}^{2}$. In contrast, the plant density in the private gardens was categorized as a medium, consisting of 10-20 plants per $50 \mathrm{~m}^{2}$ (Table 1).

Table 1. Characteristics of the farming areas in Bantul Regency

\begin{tabular}{ccc}
\hline $\begin{array}{c}\text { Farming } \\
\text { Locations }\end{array}$ & Types of Land & $\begin{array}{c}\text { Plants Density } \\
\text { (plants/ } 50 \mathrm{~m}^{2} \text { ) }\end{array}$ \\
\hline A & Paddy field & $>50$, high \\
B & Private garden & $10-20$, medium \\
C & Private garden & $>50$, high \\
D & Private garden & $10-20$, medium \\
E & Private garden & $10-20$, medium \\
F & Paddy field & $>50$, high \\
\hline
\end{tabular}

\section{Characteristics of pandan leaves from different locations}

The total chlorophyll content of pandan leaves from different farming locations is presented in Figure 2. The total chlorophyll content showed the total amount of chlorophyll in the leaves, consisting of chlorophyll $a$ and $b$, where it varied from 77.75 to $125.39 \mathrm{mg} / 100 \mathrm{~g} \mathrm{FW}$.

The results showed that high chlorophyll contents were obtained from the pandan leaves grown in $A, C$, and $D$ locations, and hence served as the primary source of materials. The pandan leaves from those locations had high chlorophyll contents because the gardens were shaded by other trees with a sunlight intensity ranging from $3605 \pm 1.83$ Lux. Zhang et al. (2015) stated that a decrease in light intensity would significantly increase the chlorophyll content of the oriental lily. The chlorophyll content of pandan leaves was similar to commercial chlorophyll from different plants. For instance, alfalfa and spinach leaves contained chlorophyll of $39-460 \mathrm{mg} / 100$ g FW (Petisco et al., 2009) and 288.02-1032.95 mg/ g DW (Deveci and Uzun, 2011), respectively. 


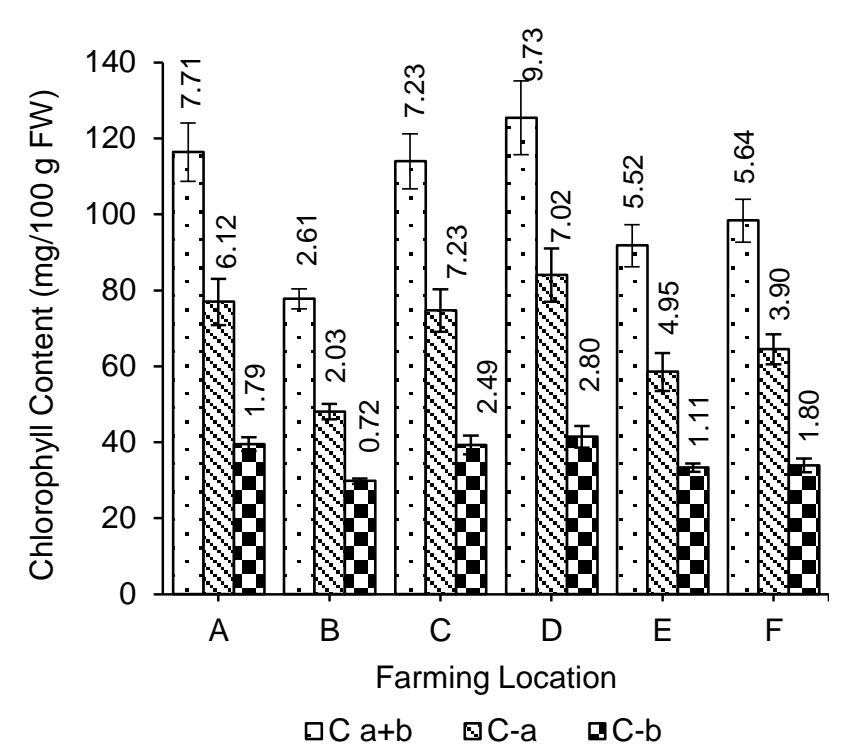

Figure 2. Chlorophyll total $(\mathrm{C} a+b)$, chlorophyll a (Ca) and chlorophyll b (C-b) of pandan leaves from different farming locations in Bantul Regency

The leaves with high chlorophyll contents had greenness (-a value) ranging from -14.56 to -15.75 , yellowness (b value) ranging from 21.29-23.57, saturation ranging from 39.89 to 46.14 , and hue angle ranging from 124.20 to 125.59 (Figure 3).

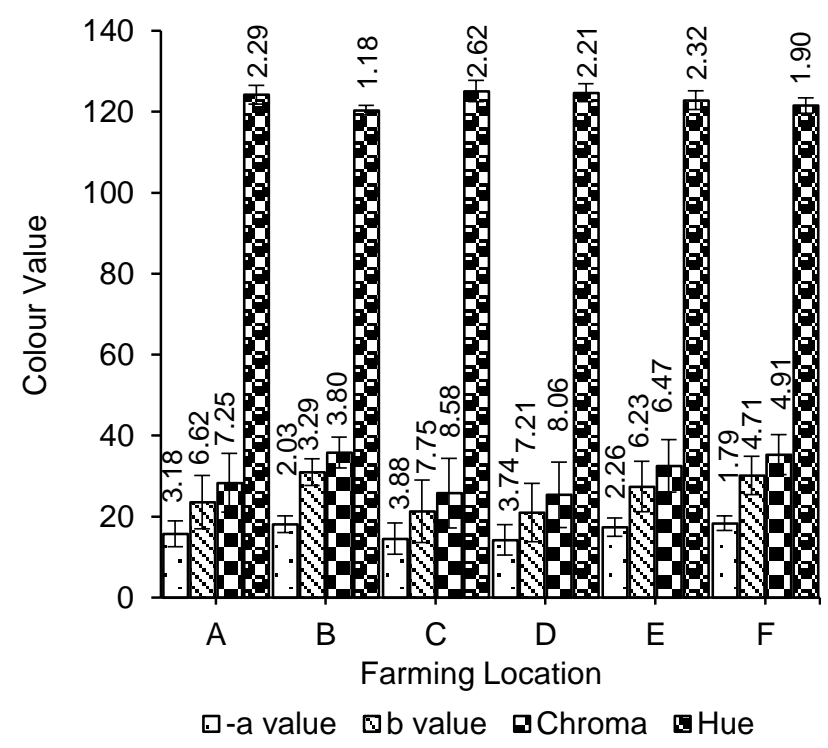

Figure 3. Color values of pandan leaves from different farming locations in Bantul Regency; greenness (-a value), yellowness (b value), color saturation (chroma) and hue angle (hue)
These results were similar to Sowndhararajan et al. (2015). They found that pandan leaves with -a value of between -7 to -15 , b value of $15-45$, and $L$ value of $30-50$, are a good source of chlorophyll. Hue values in the range of $120^{\circ}$ in the HSL color system show green, while more than $120^{\circ}$ to $160^{\circ}$ indicate bluish-green to blue. The bluish-green color is the color of chlorophyll a. Conversely, the HSL color system with less than $120^{\circ}$ to $60^{\circ}$ shows a yellowish-green to yellow. The yellowish-green color is the color of chlorophyll $b$. The results of the color study of pandan leaves from $A, C$, and D locations were identical to each other.

\section{Leaf maturity classifications}

The chlorophyll content depends on the plant types, growing condition, climate, and soils (Li et al., 2018). Furthermore, it also depends on leaf maturity (Kamble et al., 2015). Figure 4 depicts leaf numbering based on leaf maturity. The numbering starts after shoots, in which the remaining leaves bundling the stem totally (Wakte et al., 2010; Liew, 2012). Wakte et al. (2010) divided pandan leaves into six groups with the number of leaves per group ranging from three to five internodes. The grouping was carried out to select the potential leaf segment with high total phenolic contents. Gil et al. (2012) divided the leaf maturity of vegetables into three groups, namely immature, mature, and overmature. In this study, the immature was divided into young and medium. Therefore, this study used four groups of leaf maturity. The average number of leaves was $20.40-$ 23.55, rounded to 20-24. The leaves in section 1-6 were classified as young, 7-12 as medium, 13-18 as mature, and 19-24 as over mature (Table 2). The results showed that $96.4 \%$ of the plant samples had no more than 24 leaves (Figure 5).

\section{Chemical and color properties of different aged leaves}

Harvesting pandan leaves as a whole is incorrect because it will inhibit plant growth. Mataliana et al. (2015) suggested 30-35 days of cyclical harvesting. As a chlorophyll source, therefore, it is necessary to determine the optimal leaf maturity. The chlorophyll contents of pandan leaves from different degrees of maturity are shown in Figure 6 . The older the leaves, the higher the chlorophyll $a$ and the total chlorophyll content. However, in the over mature group, the increased chlorophyll content was not significanly different from the mature one. Similarly, the older the leaves, the higher the chlorophyll b. Based on the duncan's multiple range test (DMRT), the highest content of chlorophyll a and total chlorophyll was found in mature and over mature leaves. 


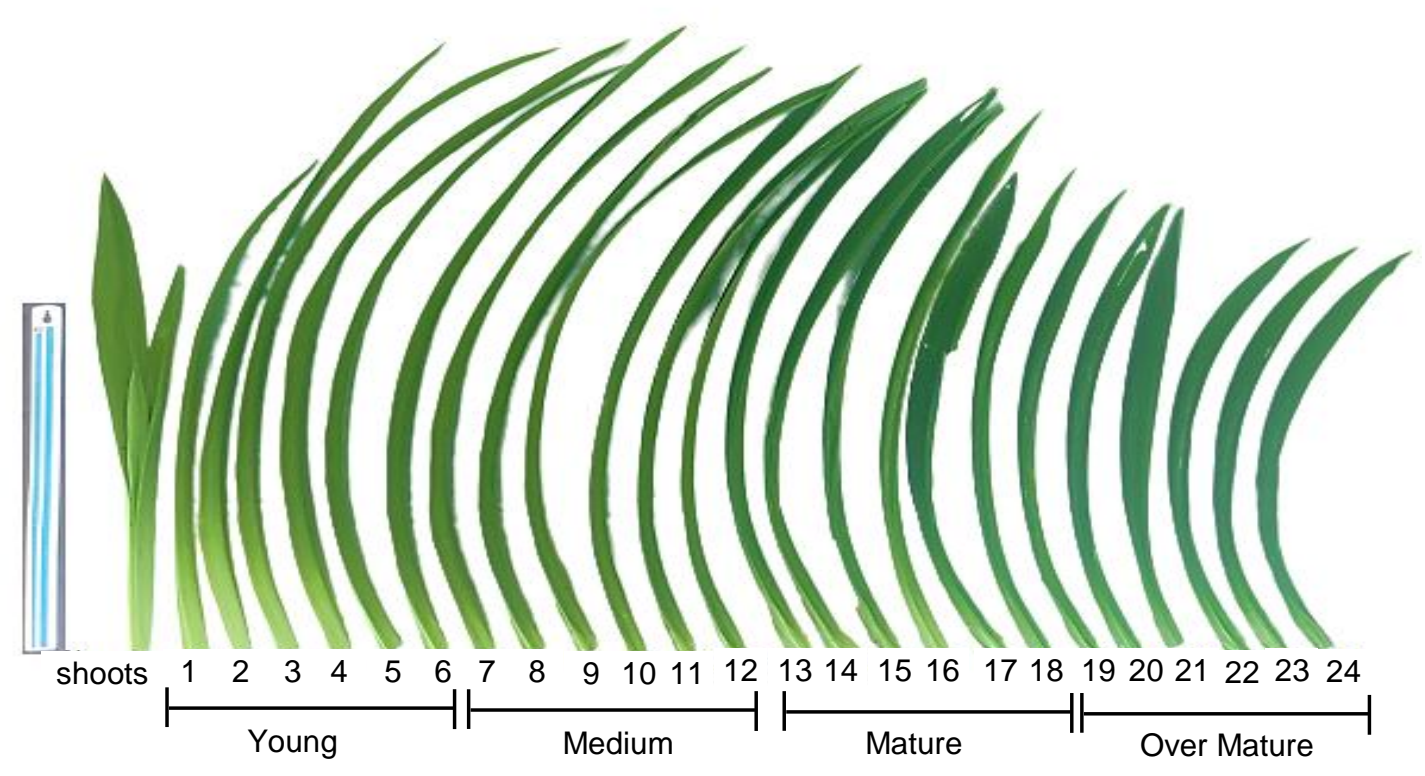

Figure 4. Leaf section numbering

Table 2. Different categories of pandan leaves based on leaf maturity

\begin{tabular}{ccc}
\hline Categories & $\begin{array}{c}\text { Leaf Section } \\
\text { Numbers }\end{array}$ & $\begin{array}{c}\text { Leaf Maturity } \\
\text { Groups }\end{array}$ \\
\hline 1 & $1-6$ & Young \\
2 & $7-12$ & Medium \\
3 & $13-18$ & Mature \\
4 & $19-24$ & Over mature \\
\hline
\end{tabular}

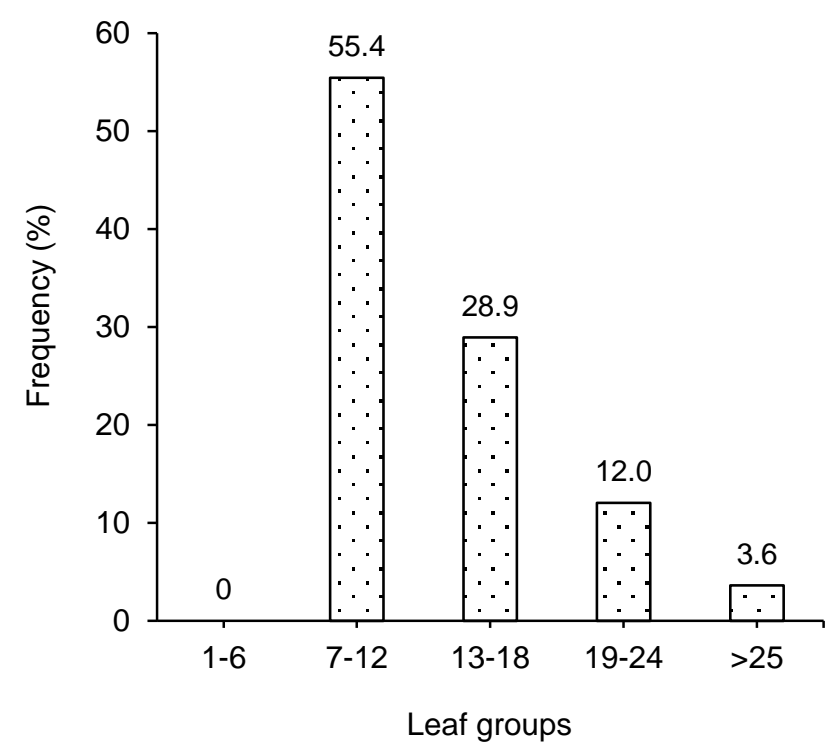

Figure 5. Frequency of pandan plants population in various leaf groups

When mature leaves were getting older, their chlorophyll a and total chlorophyll were still getting higher, and their chlorophyll $b$ was also getting higher, affecting the $\mathrm{a}, \mathrm{b}, \mathrm{L}$ and $\mathrm{C}$ values. The older the leaves, the higher the hue angle value, while the color saturation, yellowness (b value), and greenness (-a value) were smaller, but the mature and over mature leaves were not differed significantly (Figure 7). During the aging process, chlorophyll a will degrade into chlorophyllide a, pheophorbide a, and finally into non-fluorescent chlorophyll catabolite (NFCC), which is colorless (Ríos et al., 2014).

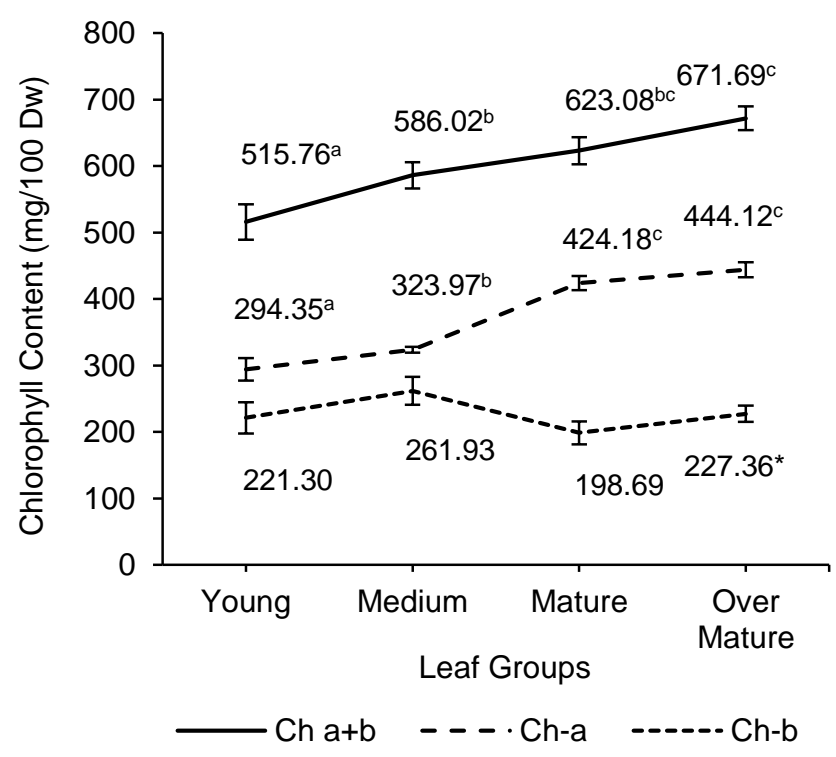

Note: Different notations ( $a, b, b c$, and c) indicate a significant difference among groups (young, medium, mature, and over mature) $(P<0.05) .{ }^{*}=$ Means are not significantly different $(P>0.05)$

Figure 6. Chlorophyll total $(\mathrm{Ch} a+b)$, chlorophyll a (Ch-a) and chlorophyll b (Ch-b) from different degrees of maturity 


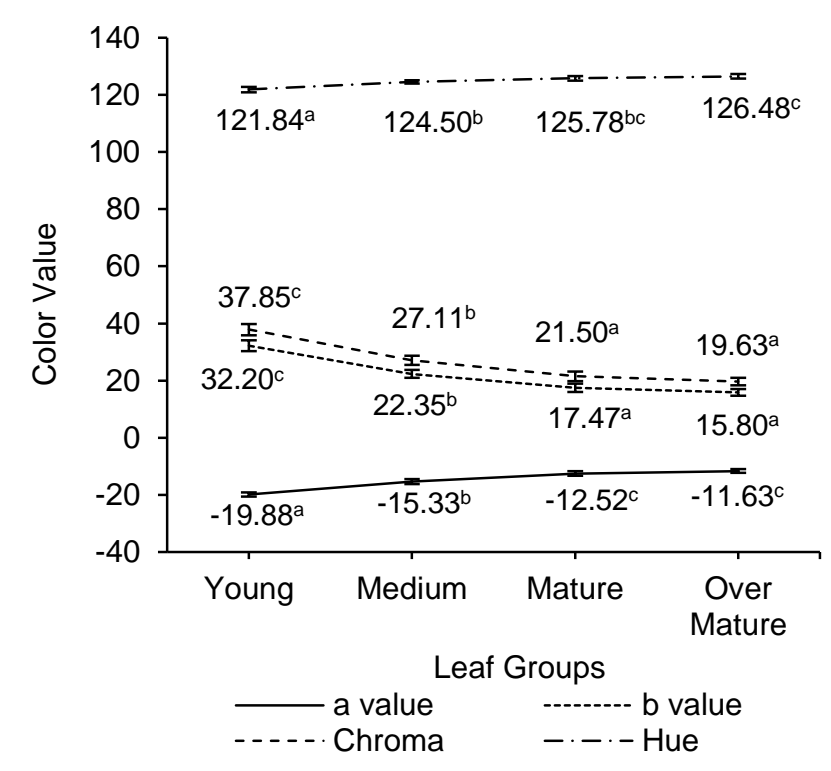

Note: Different notations (a, b, bc, and c) indicate a significant difference among groups (young, medium, mature, and over mature) or on each color parameter analyzed $(P<0.05)$

Figure 7. Color values of pandan leaves from different degrees of maturity

Table 3 shows that, as increased leaf maturity, the moisture and carbohydrate contents tended to decrease, while the protein, total carotenoid, and total flavonoid contents tended to increase steadily; and the ash, lipid, and total phenolic contents tended to increase obviously.

The increased total carotenoid was observed until the medium maturity and then remained constant afterward. Based on the results of the correlation analysis, it was known that total chlorophyll contents were significantly correlated $(P<0.05)$ with the chlorophyll a $(R=0.437)$, total carotenoid $(R=$ $0.542)$, and total phenolic contents $(R=0.468)$, but not correlated $(P>0.05)$ with total flavonoid and chlorophyll b contents. These results were different from the results of Prawira-Atmaja et al. (2018), showing that the chlorophyll contents of Camellia sinensis var. sinensis leaves were negatively correlated with the total phenolic contents. This might be because, in Prawira-Atmaja's study, the leaf segment was from 1 to 4 , while in this study, the leaf segment was wider (from 1 to 24). The total carotenoid, phenolic, and flavonoid contents provided an added value to the pandan leaves as a natural colorant besides having a specific aroma. It is known that carotenoids have antioxidant activity (Young and Lowe, 2018). The phenolic and flavonoid substances from pandan leaves also have the potency for being antioxidant (Suryani et al., 2017) and antihyperglycemic agents (Suryani et al., 2018).

\section{The anatomy of pandan leaves and their poten- tial section \\ According to the results of chlorophyll $a$ and to-} tal chlorophyll contents, pandan leaves on sections greater than 12 were a potential source of chlorophyll. In Figure 8A, the mesophyll cells are shown by a bluish-green area, where the chloroplasts are located (Figure 8B). The photomicrograph (Figure 8) clearly shows that leaves were getting thicker as increased maturity. However, the leaves became thinner when over mature. When leaves are getting older, the colorless cells occupied greater space $(\mathrm{AE})$. This indicated that the disintegration process occurred at a higher rate leading to a hollow formation. This was consistent with the results of the analysis of carbohydrate contents in over mature leaves, which tended to increase as increased fibers. The increased fibers make the grinding process more difficult (Liu et al., 2016) so that the result of chlorophyll extraction is low.

In addition, Table 4 shows that the mesophyll size was getting bigger as increased leaf maturity, but it decreased when the leaves were over mature. The chloroplast size was also getting more prominent as increased maturity, but it remained constant after the leaves reached medium maturity. According to Wild and Wolf (1980), the size of chloroplasts is very important as a source of chlorophyll as large chloroplasts have much higher chlorophyll contents than small chloroplasts. In contrast, the parenchyma length was not affected by leaf maturity. Based on the mesophyll and chloroplast size, mature pandan leaves are more appropriate as the chlorophyll source.

Table 3. Chemical properties of pandan leaves from different degrees of maturity

\begin{tabular}{llllccccc}
$\begin{array}{c}\text { Leaf } \\
\text { Groups }\end{array}$ & $\begin{array}{c}\text { Moisture } \\
\text { Contents } \\
(\% \mathrm{FW})\end{array}$ & $\begin{array}{c}\text { Proteins } \\
(\% \mathrm{DW})\end{array}$ & $\begin{array}{c}\text { Lipids } \\
(\% \mathrm{DW})\end{array}$ & $\begin{array}{c}\text { Ash } \\
(\% \mathrm{DW})\end{array}$ & $\begin{array}{c}\text { Carbohydrate } \\
(\% \mathrm{DW})\end{array}$ & $\begin{array}{c}\text { Total } \\
\text { Carotenoids } \\
(\mathrm{mg} / \mathrm{g} \mathrm{DW})\end{array}$ & $\begin{array}{c}\text { Total } \\
\text { Phenolics } \\
(\mathrm{mg} \text { EAG/ } \\
100 \mathrm{~g} \mathrm{DW})\end{array}$ & $\begin{array}{c}\text { Flavonoids } \\
(\mathrm{mg} \mathrm{EQ} / \\
100 \mathrm{~g} \mathrm{DW})\end{array}$ \\
\hline Young & $82.90^{\mathrm{c}}$ & $16.53^{\mathrm{a}}$ & $1.39^{\mathrm{a}}$ & $8.55^{\mathrm{a}}$ & $73.53^{\mathrm{c}}$ & $1.04^{\mathrm{a}}$ & $316.26^{\mathrm{a}}$ & $17.11^{\mathrm{a}}$ \\
Medium & $80.87^{\mathrm{b}}$ & $18.09^{\mathrm{b}}$ & $1.69^{\mathrm{b}}$ & $8.60^{\mathrm{a}}$ & $71.63^{\mathrm{b}}$ & $1.47^{\mathrm{b}}$ & $334.57^{\mathrm{b}}$ & $18.49^{\mathrm{a}}$ \\
Mature & $80.65^{\mathrm{b}}$ & $18.96^{\mathrm{b}}$ & $2.40^{\mathrm{c}}$ & $8.87^{\mathrm{ab}}$ & $69.77^{\mathrm{a}}$ & $1.49^{\mathrm{b}}$ & $343.64^{\mathrm{b}}$ & $18.47^{\mathrm{a}}$ \\
Over & $80.03^{\mathrm{a}}$ & $17.92^{\mathrm{b}}$ & $2.25^{\mathrm{c}}$ & $9.22^{\mathrm{b}}$ & $70.61^{\mathrm{ab}}$ & $1.50^{\mathrm{b}}$ & $386.21^{\mathrm{c}}$ & $24.48^{\mathrm{b}}$ \\
mature & & & & & & & & \\
\hline
\end{tabular}

Note: Different letters within a column are significantly different $(P<0.05)$ 


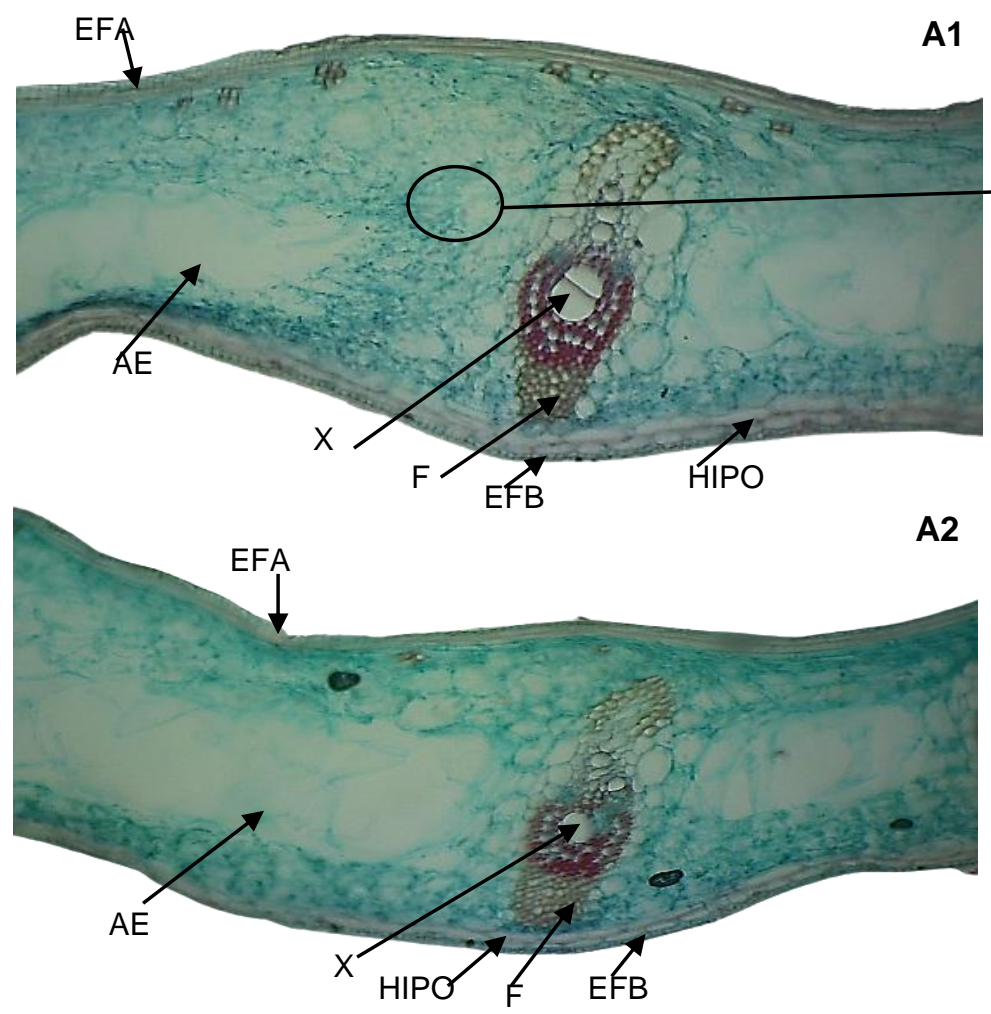

A1

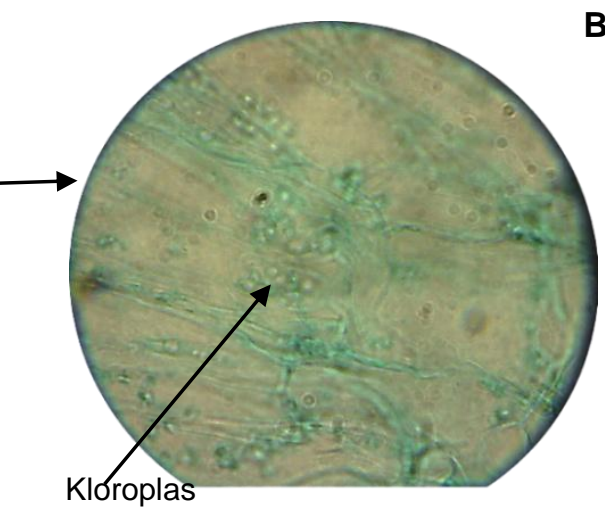

B1
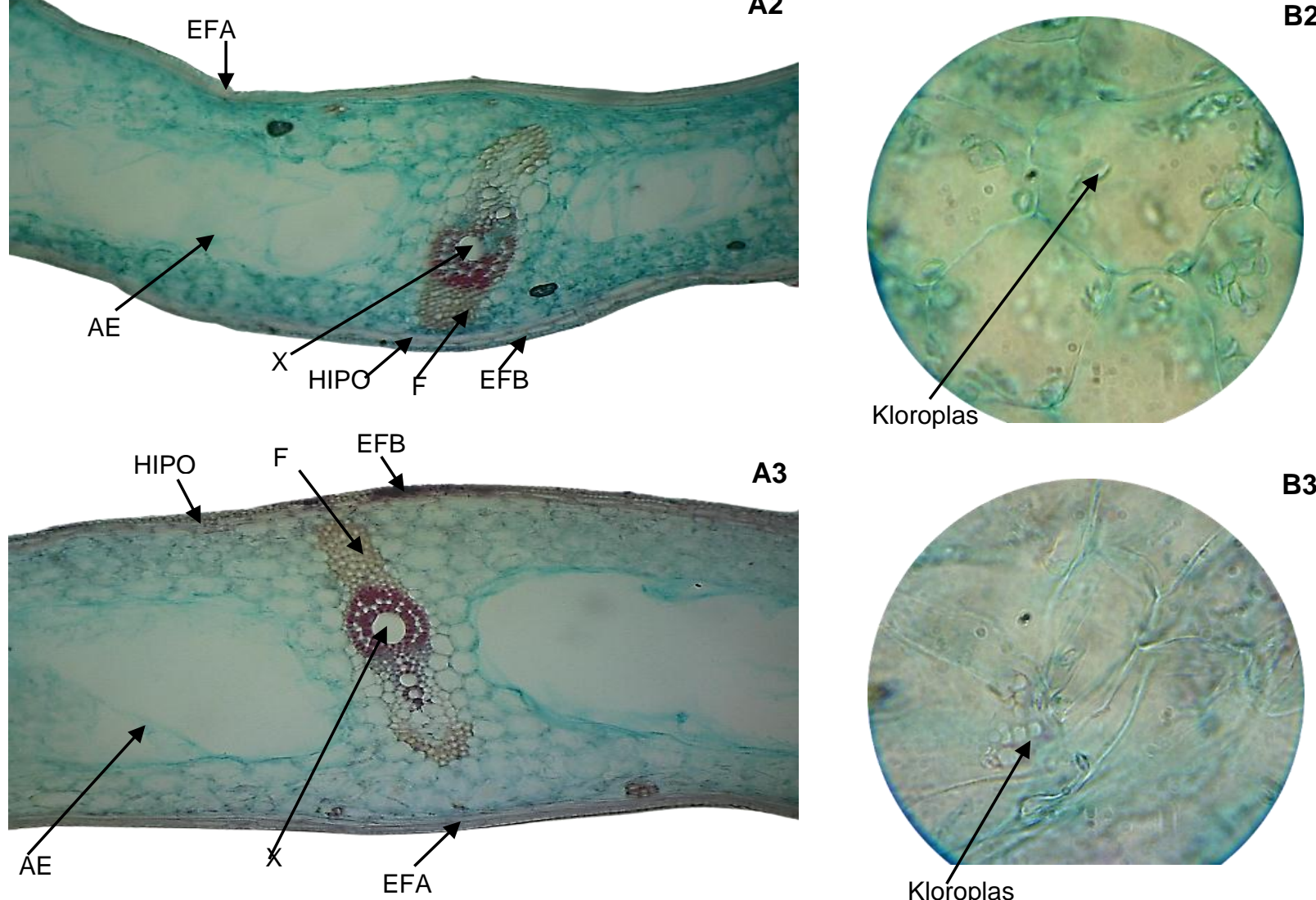

B2
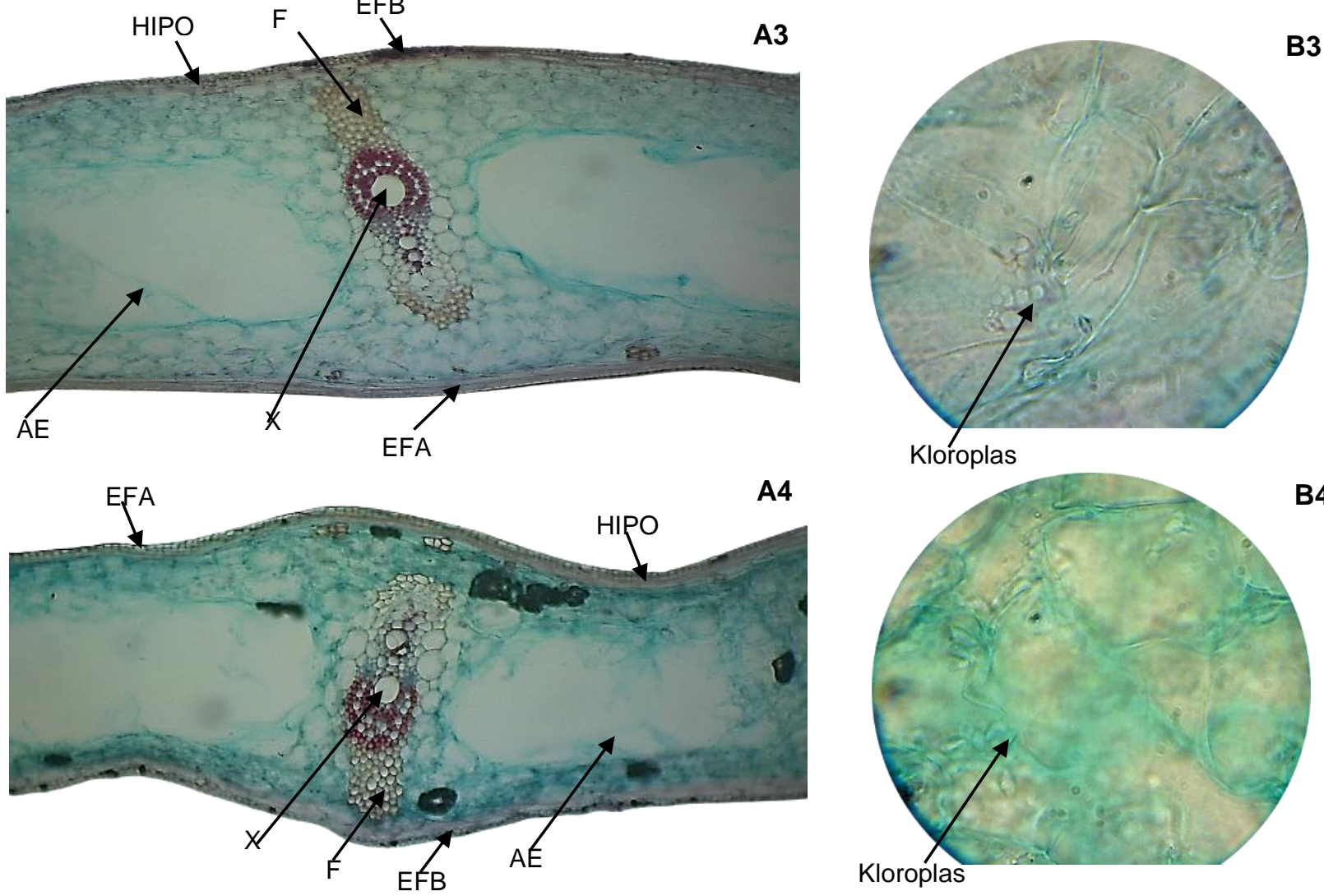

Note: Groups $1=$ young, $2=$ medium, $3=$ mature, and $4=$ over mature leaves. $E P B=$ Lower Epidermis, EPA $=$ Upper Epidermis, $\mathrm{HIPO}=$ Hypodermis, $\mathrm{F}=$ Phloem, $\mathrm{X}=$ Xylem, and $\mathrm{AE}=$ Aerenchyma. Scale Bar: $100 \mu \mathrm{m}$

Figure 8. Photomicrography of transverse sections of pandan leaves (A) and chloroplasts (B) 
Table 4. Size of mesophyll, parenchyma, and chloroplast of pandan leaves from different degrees of maturity

\begin{tabular}{lccc}
\hline $\begin{array}{c}\text { Leaf } \\
\text { Groups }\end{array}$ & $\begin{array}{c}\text { Size of } \\
\text { Mesophyll } \\
(\mu \mathrm{m})\end{array}$ & $\begin{array}{c}\text { Length of } \\
\text { Parenchyma } \\
(\mu \mathrm{m})^{\star}\end{array}$ & $\begin{array}{c}\text { Size of } \\
\text { Chloroplast } \\
\left(\mu \mathrm{m}^{2}\right)\end{array}$ \\
\hline Young & $322.80^{\mathrm{a}}$ & 690.41 & $5.35^{\mathrm{a}}$ \\
Medium & $382.49^{\mathrm{b}}$ & 681.07 & $12.31^{\mathrm{b}}$ \\
Mature & $428.20^{\mathrm{c}}$ & 731.97 & $12.60^{\mathrm{b}}$ \\
Over & $378.12^{\mathrm{b}}$ & 739.21 & $13.05^{\mathrm{b}}$ \\
mature & & &
\end{tabular}

Note: Different letters within a column are significantly different $(P<0.05) ;{ }^{*}=$ Means are not significantly different $(P>0.05)$

\section{CONCLUSION}

It can be concluded that pandan plants in Bantul Regency, Yogyakarta, Indonesia were estimated to have $20-24$ leaves with $96,4 \%$ of them had no more than 24 leaves. Based on leaf section numbering, the leaf maturity could be classified as (1) young, (2) medium, (3) mature, and (4) over mature, corresponding to leaf number 1-6, 7-12, 13-18, and 19-24 after shoots, respectively. The leaf maturity defined the chlorophyll content. The higher the leaf maturity, the higher the chlorophyll content. However, the over mature leaves were not significantly different from the mature ones. Anatomically, the greatest mesophyll size was found in mature leaves; however, the chloroplast size remained constant for leaves on sections greater than six. Based on the chlorophyll content and mesophyll size, mature pandan leaves are a good source of chlorophyll for natural food colorants.

\section{ACKNOWLEDGEMENT}

The author would like to thank the Indonesia Endowment Fund for Education (LPDP) for financial support through the Research Grant scholarship BUDI-DN 2019.

\section{REFERENCES}

[AOAC] Association of Official Analytical Chemists. 1990. Official Methods of Analysis of AOAC International, 15th Edition, AOAC, Washington.

Arnold LE, Lofthouse N, Hurt E. 2012. Artificial food colours and attention-deficit/hyperactivity symptoms: Conclusions to dye for. Neurotherapeutics 9: 599-609. DOI: $10.1007 / \mathrm{s} 13311-012-01$ 33-x.
Deveci M, Uzun E. 2011. Determination of phenolic compounds and chlorophyll content of spinach (Spinacia oleracea L.) at different growth stages. Asian J Chem 23: 3739-3743.

Gil MI, Tudela JA, Martínez-Sánchez A, Luna MC. 2012. Harvest maturity indicators of leafy vegetables. Stewart Postharvest Rev 8: 1-9. DOI: 10.2212/spr.2012.1.1.

Hörtensteiner S, Kräutler B. 2011. Chlorophyll breakdown in higher plants. Biochim Biophys Acta 1807: 977-988. DOI: 10.1016/j.bbabio.20 10.12.007.

Hu X, Tanaka A, Tanaka R. 2013. Simple extraction methods that prevent the artifactual conversion of chlorophyll to chlorophyllide during pigment isolation from leaf samples. Plant Methods 9: 113. DOI: 10.1186/1746-4811-9-19.

[IBM] International Business Machines Corporation. 2011. IBM SPSS Statistics 20 Command Syntax Reference. 20th ed. IBM Corporation.

Indrasti D, Andarwulan N, Purnomo EH, Wulandari N. 2018. Stability of chlorophyll as natural colorant: A review for suji (Dracaena angustifolia (Medik.) Roxb.) leaves' case. Curr Res Nutr Food Sci Jour 6: 609-625. DOI: 10.12944/ CRNFSJ.6.3.04.

Indrasti D, Andarwulan N, Purnomo EH, Wulandari N. 2019. Suji leaf chlorophyll: Potential and challenges as natural colorant. J IImu Pertanian Indonesia 24: 109-116. DOI: 10.18343/jipi.24.2. 109.

Institute of Food Technology. 2016. Colouring Foods and Beverages. https://www.ift.org/news-andpublications/food-technology-magazine/issues/ 2016/january/columns/food-safety-qualitycoloring-foods-and-beverages [July $20^{\text {th }}, 2016$ ].

Kamble P, Girl SP, Mane RS, Tiwana A. 2015. Estimation of chlorophyll content in young and adult leaves of some selected plants. Univers $\mathrm{J}$ Environ Res Technol 5: 306-310.

Khandaker MM, Boyce AN, Osman N, Hossain ABMS. 2012. Physiochemical and phytochemical properties of wax apple (Syzygium samarangense [Blume] Merrill \& L. M. Perry var. jambu madu) as affected by growth regulator application. Sci World J 2012: 1-13. DOI: 10. 1100/2012/728613.

Li Y, He N, Hou J, Xu L, Liu C, Zhang J, Wang Q, Zhang $X, W u X$. 2018. Factors influencing leaf chlorophyll content in natural forests at the biome scale. Front Ecol Evol 6: 1-10. DOI: 10.3389/fevo.2018.00064. 
Liew PS. 2012. Pandanus amaryllifolius-The only Pandanus with fragrant leaves. https://blogs. reading.ac.uk/tropical-biodiversity/2013/01/pan danus-amaryllifolius/ [August 21 ${ }^{\text {st }}, 2020$ ].

Limantara L, Dettling $M$, Indrawati $R$, Indriatmoko, Brotosudarmo THP. 2015. Analysis on the chlorophyll content of commercial green leafy vegetables. Procedia Chem 14: 225-231. DOI: 10.10 16/j.proche.2015.03.032.

Liu Y, Wang L, Liu F, Pan S. 2016. Effect of grinding methods on structural, physicochemical, and functional properties of insoluble dietary fiber from orange peel. Int J Polym Sci 2016: 1-7. DOI: 10.1155/2016/6269302.

Mataliana GNA, Yudhari IDAS, Dewi IAL. 2015. Keragaan usahatani pandan wangi (Pandanus amaryllifolius Roxb.) di Subak Tegenungan Desa Kemenuh Kecamatan Sukawati Kabupaten Gianyar. E-Jurnal Agribisnis Agrowisata 4: 1-9.

Mendenhall W, Sincich T. 2016. Statistics For Engineering and The Sciences. Sixth Edition, CRC Press, Boca Raton. DOI: 10.1201/b19628.

Miazek K, Ledakowicz S. 2013. Chlorophyll extraction from leaves, needles and microalgae: $A$ kinetic approach. Int J Agric Biol Eng 6: 107115.

Nikolaeva MK, Maevskaya SN, Shugaev AG, Bukhov NG. 2010. Effect of drought on chlorophyll content and antioxidant enzyme activities in leaves of three wheat cultivars varying in productivity. Russ J Plant Physl+ 57: 94-102. DOI: 10.1134/S1021443710010127.

Pathare PB, Opara UL, AI-Said FA. 2013. Colour measurement and analysis in fresh and processed foods-a review. Food Bioprocess Tech 6: 36-60. DOI: 10.1007/s11947-012-0867-9.

Petisco C, García-Criado B, García-Criado L, Vázquez-de-Aldana R, García-Ciudad A. 2009. Quantitative analysis of chlorophyll and protein in alfalfa leaves using fiber-optic near-infrared spectroscopy. Commun Soil Sci Plan 40: 24742484. DOI: $10.1080 / 00103620903111350$.

Porrarud S, Pranee A. 2010. Microencapsulation of Zn-chlorophyll pigment from pandan leaf by spray drying and its characteristic. Int Food Res J 17: 1031-1042.

Prawira-Atmaja MI, Shabri, Khomaini HS, Maulana H, Harianto S, Rohdiana D. 2018. Changes in chlorophyll and polyphenols content in Camellia sinensis var. sinensis at different stage of leaf maturity. IOP Conf Ser Earth Environ Sci 131: 012010. DOI: $10.1088 / 1755-1315 / 131 / 1 / 0120$ 10.
Pujimulyani D, Raharjo S, Marsono Y, Santoso U. 2010. The antioxidant activity and phenolic content of fresh and blanched white saffron (Curcuma mangga Val.). Agritech 30: 68-74

Rahayu SE, Kartawinata K, Chikmawati T, Hartana A. 2011. Leaf anatomy of Pandanus Spesiae (Pandanaceae) from Java. Reinwardtia 13: 305-313.

Ríos JJ, Roca M, Pérez-Gálvez A. 2014. Nonfluorescent chlorophyll catabolites in loquat fruits (Eriobotrya japonica Lindl.). J Agric Food Chem 62: 10576-10584. DOI: 10.1021/jf5036 19 s.

Schifferstein HNJ, Wehrle T, Carbon CC. 2019. Consumer expectations for vegetables with typical and atypical colors: The case of carrots. Food Qual Prefer 72: 98-108. DOI: 10.1016/j. foodqual.2018.10.002.

Senklang P, Anprung P. 2010. Optimizing enzymatic extraction of Zn-chlorophyll derivatives from pandan leaf using response surface methodology. J Food Process Pres 34: 759-776. DOI: 10. 1111/j.1745-4549.2009.00393.x.

Shimada C, Kano K, Sasaki YF, Sato I, Tsudua S. 2010. Differential colon DNA damage induced by azo food additives between rats and mice. $J$ Toxicol Sci 35: 547-554. DOI: 10.2131/jts.35. 547.

Simon JE, Decker EA, Ferruzzi MG, Giusti MM, Mejia CD, Goldscgmidt M, Talcott ST. 2017. Establishing standards on colors from natural sources. J Food Sci 82: 2539-2553. DOI: 10.11 11/1750-3841.13927.

Sowndhararajan K, Chin NL, Yusof YA, Lai LL, Mustapa WAW. 2015. Effect of blender and blending time on colour and aroma characteristics of juice and its freeze-dried powder of Pandanus amaryllifolius Roxb. leaves (Pandan). Int J Food Eng 12: 75-81. DOI: 10.1515/ ijfe-2015-0096.

Suryani CL, Tamaroh S, Ardiyan A, Setyowati A. 2017. antioxidant activity of pandan (Pandanus amaryllifolius) leaf ethanol extract and it's fractions. Agritech 37: 271-279. DOI: 10.22146/ agritech.11312.

Suryani CL, Tamaroh S, Budipitojo T. 2018. Increased of hypoglycemic effect and pancreatic regeneration of Pandanus amaryfollius leaves ethyl acetate extract in streptozotocin-induced diabetic rats. Int Food Res J 25: 1792-1798.

Viera I, Pérez-Gálvez A, Roca M. 2019. Green natural colorants-a review. Molecules 24: 1-17. DOI: 10.3390/molecules24010154. 
Wakte KV, Nadaf AB, Thengane RJ, Jawali N. 2009. Pandanus amaryllifolius Roxb. cultivated as a spice in coastal regions of India. Genet Resour Crop Ev 56: 735-740. DOI: 10.1007/s10722009-9431-5.

Wakte KV, Thengane RJ, Jawali N, Nadaf AB. 2010. Optimization of HS-SPME conditions for quantification of 2-acetyl-1-pyrroline and study of other volatiles in Pandanus amaryllifolius Roxb. Food Chem 121: 595-600. DOI: 10.1016/j. foodchem.2009.12.056.

Wakte KV, Zanan RL, Saini A, Jawali N, Thengane RJ, Nadaf AB. 2012. Genetic diversity assessment in Pandanus amaryllifolius Roxb. Populations of India. Genet Resour Crop Ev 59: 15831595. DOI: 10.1007/s10722-012-9882-y.
Wild A, Wolf G. 1980. The effect of different light intensities on the frequency and size of stomata, the size of cells, the number, size and chlorophyll content of chloroplasts in the mesophyll and the guard cells during the ontogeny of primary leaves of Sinapis alba. Zeitschrift für Pflanzenphysiologie 97: 325-342. DOI: 10.10 16/S0044-328X(80)80006-7.

Young AJ, Lowe GL. 2018. Carotenoids-Antioxidant properties. Antioxidants 7: 10-13. DOI: 10.3390/ antiox7020028.

Zhang YJ, Yan F, Gao H, Xu YZ, Guo YY, Wang EJ, Li YH, Xie ZK. 2015. Chlorophyll content, leaf gas exchange and growth of oriental lily as affected by shading. Russ J Plant Physl+ 62: 334-339. DOI: 10.1134/S1021443715030206. 